\title{
2 British Cultural Studies
}

\author{
The kise and rall of cuturai studies \\ A culdural Mistory of culcural sudies

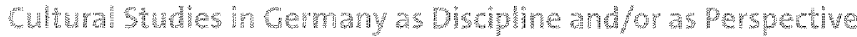

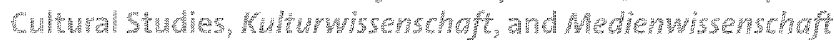 \\ Theory and Mehodology of Cutural (Media) Studies \\ Puture cultural Medial studies
}

Cultural Studies is dead! Its spiritual home, the Centre for Contemporary Cultural Studies (CCCS) in Birmingham, had to close its doors in 2002, not quite forty years after its inauguration in 1964. In the USA, where British Cultural Studies found a new home (cf. entry III.3), loud demands for "Stopping Cultural Studies" can be heard (Warner and Siskin), and plans for a life at "The University After Cultural Studies" are already being made. (Such was the title of a plenary panel at the seventh annual meeting of the Cultural Studies Association in Kansas City in 2009.) What would it mean, however, to stop doing cultural studies? Would it mean that we stop analysing the texts, films, plays, images, and songs that contribute to our cultures? Does it mean that we no longer examine the artefacts and symbols that form (British) ways of living? It does not.

Long live cultural studies! To stop doing (British) Cultural Studies means only to stop studying culture one particular way. The aim of this text is to first trace the paths that led to the ends, but also to the beginnings of British Cultural Studies. Following this account will be an outline of what the study of culture could look like after the demise of British Cultural Studies. My perspective on the history and place of cultural studies is one originating within the field of English Studies in Germany (Anglistik) — one of the many disciplines that gave a fruitful home to British Cultural Studies. The following remarks, therefore, will switch between a description of cultural studies as it was first formed in Great Britain on the one hand, and an outline of English Studies (in Germany) as a mode of cultural studies on the other. British Cultural Studies, consequently, means two things to me: cultural studies as it has been practiced in Britain, and the study of the cultures of Britain.

\subsection{The Rise and Fall of Cultural Studies}

In order to understand what British Cultural Studies is, one has to understand its use. Cultural studies, just as every other discipline or research paradigm, is bound up in the history of social and scientific structures: it is not just an artefact of intellectual, theoretical achievement ('learning'), but also rooted in social practices and mentalities ('a whole way of life'). Therefore, I will begin by examining one of the stories which try to make sense of the relationship between Anglistik and cultural studies. The analysis of such stories (i.e. narratology) and their intended effects (i.e. rhetoric) are central tools for the study of culture, a culture of which cultural studies is a part.

current condthon. When two of the leading figures of English Studies in Germany were asked to define the status quo of 'English Studies Today' they strongly expressed their disappointment in the current condition of the discipline. It appears helpful to take a closer look at the somewhat provocative, but nonetheless very representative story these authors have to tell about the causes for this demise. The two professors are clear about what they do not like about the present state of English Studies: they criticise the "disorders of our academic minds" (Nünning and Schlaeger 14) and the "centrifugal forces" (14) that have led to the "unfocussed and fragmentary nature" (13) of the field, which reveals a lack of even "a modicum of unity and coherence" (15); not even some sort of "common purpose and standards or shared preferences" (12) are discernible. If disorderly behaviour
Anstory of

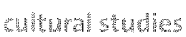


Culuel studies and philology: A compli. cated relationship is the offence, the prosecution is, however, less straightforward in naming the accused. The first time that one is allowed a glimpse of the culprit is in the form of a (rhetorical) question: "If you don't like Byron, Dickens, Eliot or Marlowe why not occupy yourself with Batman, Diana, Eminem or Madonna, or Manchester United, for that matter?" (11). All that is rotten in the state of English Studies, it transpires, seems to be fruits from the fields of non-literary popular culture-a classical topic of cultural studies, that is (cf. section III.3.3).

Rise. After enumerating various examples of misled research, the authors become somewhat more precise. First, they claim that the rise of 'Theory,' and poststructuralism in particular (cf. entry II.4), led to a "loss of prestige of our disciplines" (Nünning and Schlaeger 18). At this moment of crisis, when English Studies was at its weakest, enfeebled by the infection from (frenchified) "intellectual coteries" (17), cultural studies apparently took over a defenceless English Studies: "The vacuum was filled by the next candidate in line: cultural studies" (18). At the beginning, the authors admit, the newcomer was not without merits as it "not only allowed literary scholars and, to a certain extent, also linguists to focus their attention on cultural utterances that had been deemed not worth the effort until then" (18). It also strengthened English Studies' "claims for social relevancy through the inclusion of political agendas which seemed to move the field right back into the centre of contemporary intellectual, political and ethical concerns" (18). With the traditional canon of 'good literature' apparently destroyed by postcolonial, feminist, Marxist, and poststructuraIist theories (cf. entries III.4, II.6, II.2.3, and II.4 respectively), cultural studies and its emancipatory project seems to have promised to revive a dwindling discipline: with cultural studies, one was able to explain why (ordinary) people read/ watched what they actually read/watched, not what they should read (and should not watch).

Fan. Such rise in relevance was not to last, however. Even though cultural studies might have had its time providing giddy "excitement" and "interesting perspectives" (Nünning and Schlaeger 18), its unorganised descriptions of the ordinary should be shown the door now in order to make room once again for more serious matters. The argument is more suggestive than logical, resting on little backed premises, but obvious nonetheless: a) cultural studies invaded what "was once a more or less unified philological discipline" about "three decades ago" (8), b) since then, cultural studies lost its "relevancy and prestige" (18) outside English Studies; ergo: English Studies spiralled into "uncontrolled diversification and fragmentation" (18). Although the authors are quick to add that "there is probably no direct causal link" (18) between the rise (and fall) of cultural studies and the demise of English Studies, the chronological correlation, and especially the fact that no other possible causes are considered, suggest otherwise. Finally, the question of (British) Cultural Studies becomes the question of the future of English Studies (in Germany): "Quo vadis, Anglistik?" (7)

outook. The authors are cautious when it comes to suggesting how to restore unity, order, and coherence once cultural studies has been dismissed. The final lines of the 'argument' against cultural studies, however, offer us at least an inkling of what they consider to be the centre of English Studies when they speak of "English Studies and other modern philologies" (Nünning and Schlaeger 18). English Studies, it appears, is essentially a study of words (and reason), i.e. texts, and as neither Diana nor Madonna nor ManU are especially famous for primarily textual outputs, they should not be studied by philologists. And indeed, they should not. If we keep defining English Studies as 'philology,' there are good reasons to exclude Madonna, Diana, and the rest of the ladies from the playing field-and return, hardened through the experience of crisis, to the more serious and reasonable utterances of Byron, Dickens and Eliot. The more interesting question, however, is whether English Studies should really (still) be considered a philological enterprise. The term might, although even that is doubtful, give a home to both Literary Studies and Linguistics, but it surely excludes cultural studies in any meaningful sensethat is, in a sense that goes beyond understanding 'culture as text' (Huck and Schinko).

Instead of suggesting a restorative solution to the problem of English Studies by bringing philology in line against cultural studies, I would like to suggest a model for the study of culture(s) that might not threaten, but instead stimulate English Studies. Such a model would not aim at providing (idealist and normative) orientation in an ever more complex society (Frühwald et al.); nor would it content itself with mere (empiricist and arbitrary) descriptionism. Rather, a methodological examination of contingency as modern society's defining attribute (Luhmann, Observations) could disclose the interdependency of meaning 
and materiality for every world-observing actor, reveal latent potentialities, and create new possibilities. In order to develop such a future model of English Studies as cultural (media) studies, I want to go back to the beginnings of cultural studies in Britain.

\section{2 | A Cultural History of Cultural Studies}

Cultural studies began with an attack against the traditional canon of English Studies as it was represented in the work of New Critics (cf. section II.1.3). Two texts are commonly identified as the starting point of cultural studies: The Uses of Literacy by Richard Hoggart, from 1957, and Culture and Society by Raymond Williams, published only a year later. Both texts propagate the notion that there is no such thing as an elite culture, but only an elitist view of culture (Lindner, Stunde 20); both texts emphasise that (high) culture ('arts and learning') and society ('a whole way of life') are always interdependent, that literacy is a question of use, that art is always related to life.

In his introduction to Culture and Society, Williams traces back the meaning of the word 'culture' to conclude that whereas "culture meant a state or habit of the mind, or the body of intellectual and moral activities, it means now, also, a whole way of life" (xviii). Culture, Williams stresses, is not just Byron, Dickens, Eliot, but everything that gives meaning to people's lives in specific social circumstances-and that could also be Diana, Madonna, or ManU. It does not mean, however, that Byron's poems are not culture-they are just not all there is, and they do not mean the same for everyone. And neither does it mean that all cultural products are the same, or that they all have the same function.

From an exclusive idea of culture as the "best that has been thought and said in the world" (Arnold 52) Williams moves to an anthropological, inclusive notion. Williams calls this new understanding "the 'social' definition of culture, in which culture is a description of a particular way of life, which expresses certain meanings and values not only in art and learning but also in institutions and ordinary behaviour" (Long Revolution 41). Consequently, society can no longer be divided into a cultivated bourgeoisie and an unrefined lower class-and 'high' cultural products could no longer hold to represent all of British culture.

It is this objection against a narrow definition of culture as a collection of great works and the demand for the recognition of working class life as being 'cultural' that gave rise to the project of cultural studies. While such an enlarged notion of culture might appear to us today as a sound theoretical construct, it nonetheless emerged from a vital personal experience of difference and a subsequent demand for a practice of recognition. And it is this experience of cultural difference (and unity) that, above all, gave momentum to the emergence of cultural studies. Cultural studies, from the beginning, was more than just an academic project.

Hoggart formulates the particular social and psychological conditions of 'scholarship boys' in a chapter of The Uses of Literacy. Although, as Hoggart points out, there are 'scholarship boys' who feel comfortable in their new environment, a great number of 'boys' depart from their original (working class) milieu without ever fully arriving-and subsequently feeling at home-anywhere else. Instead, they are stuck "at the friction-point of two cultures" (225). Aspiring to social advancement and being dissociated from his family to a certain degree, the 'scholarship boy' can no longer fully identify with working class val-

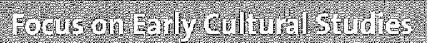

In order to understand the relation between theory, experience, and practice it is helpful to look at Williams and Hoggart's life-narratives, which reveal similar social experiences. Hoggart, born in Leeds in 1918, grew up in a working class district with his grandmother, who supported his educational efforts that would lead to a scholarship for the University of Leeds (Lindner, "Hoggart" 165-6). Williams was born into a Welsh family in an agrarian environment in 1921; his father was a railway worker, but the rest of his family had been working on farms for generations ("Culture is Ordinary" 3-4). Like Hoggart, Williams was the first person in his family to come into contact with higher education, earning himself a scholarship to Cambridge. They both represented a new generation of British intellectuals of the 1950s who came from a working class environment and attended secondary schools and then (elite) universities on a scholarship. Various political, social, and economic changes in post-WWII Britain made these careers possible (e.g. Education Act 1944), as well as international developments (e.g. Stalinism, Cold War) (Winter). What I want to look at here are the intellectual consequences of such careers (Bromley, Lindner, Stunde, and Sommer, "From Cultural Studies"). 
ues (integrity, solidarity), but neither wholeheartedly adopt middle-class values (betterment, individuality).

Williams seems to overcome this inability to relate acquired knowledge to working class experience and, apparently, combines the two parts of his identity. Nevertheless, since he has moved away from his social origins but still identifies with the working class, he feels located in a "border country" ("Culture is Ordinary" 7). The double affiliation to these two cultures, without fully belonging to either, makes Williams a 'cultural hybrid' who is able to analyse working class culture from within but with the attitude of an outsider (Lindner, Stunde 25). This outside perspective on the familiar seems to be the essence of Williams' and Hoggart's intellectual productivity (Williams, "Future" 152, 156).

Rolf Lindner, an ethnologist of Western culture, argues that working class culture could be lived without reflecting that it actually is a form of culture because it has traditionally been thought of as a natural state of being (Stunde 46) - in contrast to the cultivated, or rather: civilised middle and upper class. It is the comparison of one's own habits with another's, however, that enables self-reflexivity, and only the 'scholarship boys' had the required cognitive competence to bring their individual experience to bear on theory. The autobiographic parallels in Hoggart's and Williams' career form a generational theme that made itself Sonthito

While $\rightarrow$ cuture is often used synonymously with the term 'arts,' another, anthropological tradition understands culture to refer to a structured collective of humans. E. B. Tylor, for example, defined culture as "that complex whole which includes knowledge, belief, art, morals, law, custom, and any other capabilities and habits acquired by man as a member of society" (1:1). However, as Gregory Bateson has shown, culture is not a given set of characteristics defining social groups, but a means of comparing, distinguishing and thereby first of all creating these groups. Cultures, thus, are contingent constructions. Raymond Williams, finally, emphasises that "we use the word culture in [...] two senses: to mean a whole way of life-the common meanings; to mean the arts and learning - the special processes of discovery and creative effort. Some writers reserve the word for one or the other of these senses; I insist on both, and on the significance of their conjunction" ("Culture is Ordinary" 4). To be more precise, Williams actually distinguishes three aspects of culture: (a) material artefacts, (b) observable social behaviour (e.g. institutions, habits), and (c) the unobservable and not yet fully figured 'mentality' behind this behaviour. To analyse the conjunction of these aspects is a central tenet of cultural studies. felt not only in the academic world, but in the fields of political and artistic activities, too (Lindner, Stunde 27, 36). Their position in-between two cultures provided this generation with the potential to see the community they left with different eyes (92-93). Artists and academics alike were able to express the specificity of working class culture in the academic and artistic vocabulary of the traditional cultural elite-and demand recognition for a culture that hitherto had been neglected at best, and denigrated at worst.

\subsection{1 | Marginalised Expressions of Culture}

As a consequence of such experiences, the objects of research in cultural studies pre-eminently used to be cultural groups that were socially underrepresented, as well as cultural products that had formerly been excluded from the canon of English Studies (Hall, "Emergence" 21). The aim of cultural studies was to bring recognition to marginalised expressions of culture, and to recognise these expressions as cultural in the first place. Here was a generation of scholars who had to find out that huge parts of their lived experience were not represented in the academic world-and that those works that were present were analysed by New Critics without reference to "those social, cultural, ideological, regional, and generational" (Weimann 261) forces that shaped their form and content. Williams and Hoggart had experienced first-hand that one reads texts differently according to one's social background, and that one chooses different cultural products according to one's social environment, one's habits, rather than one's intellectual capacity. As a consequence, both bringing new texts into the classroom and explaining old texts differently, but also understanding the formation of different cultural groupings that determine one's taste in and appreciation of cultural products, became the central objectives of cultural studies.

Cultural contact as experienced by Williams and Hoggart is the prerequisite for a culture to be recognised as a 'culture' at all (Baecker 16): neither the bourgeoisie nor the working class were considered (contingent) cultures before they met on equal terms-however cultivated they might have been; rather, they were considered as more or less civilised. Varying forms of behaviour, however 
unrealised, are at the same time a prerequisite for recognizing difference. Cultures, consequently, become relative terms: their existence and their identity rely on the chosen reference group: this could be a class, a nation, a gender, a religion, a region, an ethnicity, etc. Cultural studies, consequently, came into being when culture, as a level of comparability between compared groups, was discovered in cultural contact.

The insistence on culture in the anthropological sense opened English Studies (in Great Britain) to new concerns: cultural difference and the power relations that govern the relations between different cultures on the one hand, and the relation between cultural texts and lived experience on the other. The anthropological sense of culture made the study of cultural products (books, films, etc.) by no means obsolete: Williams, for example, develops an interest in the complex relations between what he calls "structures of feeling"-defined "as social experiences in solution, as distinct from other social semantic formations which have been precipitated and are more evidently and more immediately available" (Marxism and Literature 133-34) - and cultural products, that is, between "meanings and values as they are actively lived and felt" (132) on the one hand, and concrete cultural products such as texts and films on the other. While for Williams culture encompasses not only material artefacts, but also the observable social behaviour and the underlying unobservable 'mentality' (see box), it is the relation between all of these aspects that is central to his vision of cultural studies.

\subsection{2 | The Centre for Contemporary Cultural Studies}

The position on the margins of culture, or rather: in the contact zone of cultures, applies to many who worked for the Centre for Contemporary Cultural Studies in (the marginalised city of) Birmingham, which was founded in 1964 by Richard Hoggart (Hall, "Emergence" 12). Stuart Hall, Hoggart's assistant and successor as director of the CCCS, shifted the focus of cultural studies away from cultural products in the sense of 'arts and learning' towards more sociological questions, where cultural products play a vital, but nonetheless secondary role. Hall was born in Jamaica of African descent and moved to Britain in the early 1950 s as

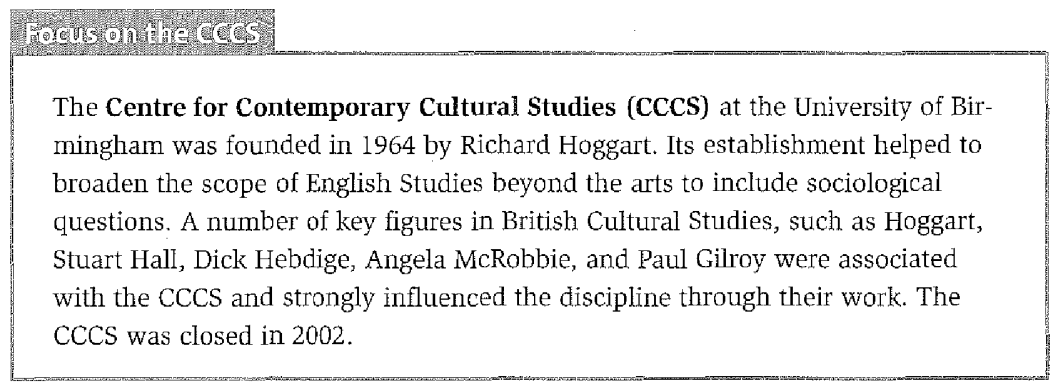

part of the Windrush generation; again, a scholarship paved his way to study in Oxford, and once again, the experience of cultural difference led to a theoretical interest in culture (Interview 13). Hall, after studying English Literature in Oxford, went on to become professor of sociology at the Open University and president of the British Sociological Association; with him the CCCS moved from the English Department to that of Sociology. Rather than looking for a (lost) working class culture, Hall's research concentrated on the role of the mass media in organising society and the (active) role of the audience in consuming popular culture. Central to Hall's concern became the question of how cultural products contributed to the constitution of a hegemonic culture-a culture, that is, which convinces people to act according to an ideology that is not necessarily beneficial to their own life without coercing these people (by force).

Several graduates from the CCCS expanded the field of cultural studies in important directions. Paul Willis introduced ethnographic methods to study the resistance of subcultures to hegemonic culture; these new research methods (participant observation, interviewing) made it possible to highlight the appropriations of cultural products in actual use. Dick Hebdige concentrated on those material expressions of youth and subcultures that subverted the official, hegemonic use; such recognition of subcultures opened the way for understanding the heterogeneity of any culture/society. Paul Gilroy focused on ethnic representations of national identity and the marginalisation of migrant identities, criticizing especially the (outdated) idea of the Empire. Angela McRobbie emphasised the relevance of (hierarchical) gender relations for youth and other cultures. Consequently, when the CCCS was finally closed in 2002 , fields of research included the role of popular culture and mass media in the (hegemonic) formation of society; the ways in which gender, ethnic, and class habits, but also experiences of 


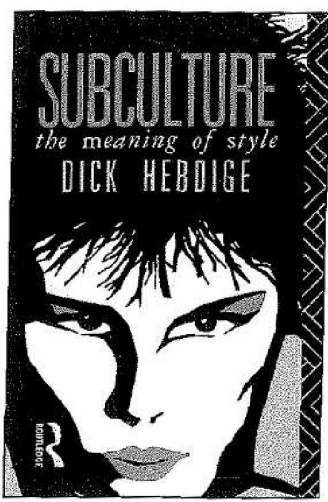

Dick Hebdige put the focus on subcultures.

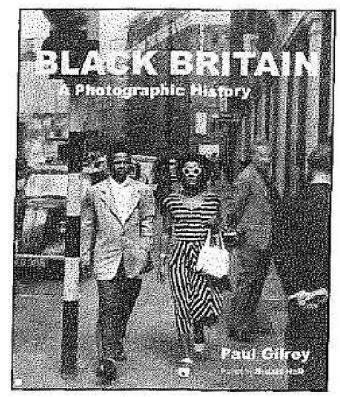

paul Gilroy pioneered She sudy or black lite in Brtain. sexual orientation, age, and ability structure power relations within society; possibilities of resistance to hegemonic culture. While cultural studies began with an agenda of recognition, it soon had to put questions of identity and difference at the centre of research. From now on, (representational) identity politics rule: if culture is a construct, it can be made and re-made.

Arrival in Cemany. It is in this later form that (British) Cultural Studies arrived in Germany. When Jürgen Kramer and Bernd Lenz welcomed cultural studies in their inaugurating editorial to the newly founded Journal for the Study of British Cultures, they characterised it as follows: "It has been predominantly, but by no means exclusively, concerned with analytical categories (such as class, 'race'/ethnicity, gender, nation/nationality, language, generation) and with signifying processes, above all the mass media and their wide-spread cultural products. Thus, its main objective has been to analyse social and signifying processes on the one hand and processes of identity formation on the other" (5). As a consequence, the authors recommend that "Departments of English and American Studies" incorporate cultural studies of the following form "in their research and teaching" (5): "The objects of Cultural Studies in research and teaching can be grouped under three headings:-social processes (historical developments, political institutions, the economy etc.);-signifying processes (the arts, the media, life styles etc.);-processes of identity formation (mentalities, social roles, norms and values etc.)" (4). It is this wide definition of cultural studies that came to be viewed as a cause of disorder and fragmentation only a decade later by Nünning and Schlaeger.

critisisms. There are a number of criticisms that have been brought forward against this (later) version of cultural studies: too much emphasis on popular culture without regard to aesthetic concerns (of literature); as a consequence, too much emphasis on contemporary culture, which is, unfortunately, dominated by popular culture, and a subsequent lack of historiography; a "politically (and ideologically) correct type of moralism" (Weimann 264) instead of a scientific methodology and a sound theoretical framework. Even the most prominent figure within British Cultural Studies, Stuart Hall, seems to be weary of the direction in which cultural studies is heading: "I really cannot read another cultural studies analysis of Madonna or The Sopranos" (Interview 29). Why? Because it is too political (i.e. 'left'), too populist, too contemporary, too un-scientific, too disorderly? No. Hall's disappointment in the state of the discipline stems from quite different expectations. Hall is concerned by the fact that "cultural studies ceased to be troubled by the grubby worldliness $[. .$.$] , the worldliness in which culture has$ always to exist" (Interview 28). Cultural studies, it seems, had come full circle: where the New Critics had ignored culture as a 'whole way of life' because they believed literary texts to exist independently of such life, the 'New Culturalists' seem to think they can ignore culture as a 'whole way of life' because everything is a text anyway; in the end, these practitioners of cultural studies turn out to think as a-historically (and a-materially) as their predecessors.

\subsection{Cultural Studies in Germany as Discipline and/or as Perspective}

If the objects of cultural studies in Germany are to be all those things that Kramer and Lenz (5) enlist, many have to practice cultural studies: historians, political scientists, economists, art historians, musicologists, sociologists, anthropologists, ethnologists, etc. Since the so-called cultural turn, everything that used to be humanities (Geisteswissenschaften) has been remodeled as some sort of cultural studies (Kulturwissenschaften): everything that humans create (artefacts), or even think (mentalities) or do (actions), is culture. In this rather unspecific sense, 'cultural studies' does not so much denominate a discipline, but a perspec- tive-a perspective that can shed more or less light on (nearly) everything. However, if Kulturwissenschaft wants to be anything more than Geisteswissenschaft's new clothes, it has to provide a third space rather than an alternative (Eagleton 4-5, Stierstorfer 11): instead of looking for empirically observable laws (Naturwissenschaft) or philosophical ideas and subjective intentions (Geisteswissenschaft), the cultural turn suggests that one look for contingent patterns of meaning that structure economic, political, and social relations and which are articulated (Hall, "On Postmodernism and Articulation") in books, films, paintings, 
songs, buildings, billboards, etc. 'Contingency' as a new research paradigm might be able to mediate between the strict opposition of a two-cultures paradigm that sets mind in opposition to matter, subject against object, history against nature, tekhnè against physis, autonomy against heteronomy, freedom against determination. Under this new perspective, a reformed English Studies would be a sub-discipline of Kulturwissenschaften-that sub-discipline that concentrates on the English-speaking world.

On the other hand, however, cultural studies is a sub-discipline of English Studies (Anglistik). English Studies, then, consists of Literary Studies, Linguistics, and cultural studies, complemented by Language Training and Didactics for those training to become teachers (Sommer, Grundkurs 13). Under this paradigm, the manifold tasks that Kramer and Lenz (5) enumerate have, obviously, to be cut down to size, as to attempt all of them from within English Studies would indeed seem a somewhat hubristic enterprise bound to end in dilettantism. The obvious way to scale down cultural studies seems to be to enclose it within the field of philology: "English (cultural) studies in Germany remain [sic] a textual or interpretive science [...] This emphasis on textual(ised) culture marks the disciplinary boundary between hermeneutic, and historical studies of cultural representation on the one hand and sociological research on the other" (Sommer, "From Cultural Studies" 172). While Williams and Hall worked towards a combination of hermeneutic/historical and sociological research, although with different emphases, many within English Studies re-emphasise this disciplinary boundary.

Using Williams' terminology, one could say that English Studies has tried to open the category of 'arts and learning' to even those objects that are part of a 'whole way of life' - without however trying to approach this 'whole way of life,' i.e. social behaviour, habits and institutions, which are considered to be the object of sociology or anthropology; this way, English Studies was superficially, i.e. in terms of its objects of research, able to renew itself, without, however, having to question its practice of research, i.e. reading texts. While, on the surface, English Studies gained relevance through opening itself to cultural studies, it stretched its traditional framework without being willing to renew its own foundation.

Solutions. Practically, the conundrum that English Studies is as much a sub-discipline of a gen- eral Kulturuissenschaften as cultural studies is a sub-discipline of English Studies has led to a number of solutions. One attempt can be found in accumulating the various disciplines that study the culture of Britain (or the USA) in an interdisciplinary centre. The Großbritannienzentrum in Berlin-similar to the John F. Kennedy Institut für Nordamerikastudien-brings together historical, political, economic, juridical, literary, and linguistic studies concentrating on British culture. To think of cultural studies as a discipline is not necessary according to this conception, as it becomes the perspective under which diverse disciplines collaborate

However, those forms of Literary Studies that contribute to such collaborations are often understood as a mode of a general cultural studies. Such Kulturwissenschaftliche Literaturwissenschaft ('cultural studies literary studies') analyses literary works as "media expressions through which a culture becomes observable" (Nünning and Sommer 19; my trans.) and concentrates on a text's relations to its context, the 'mentalities' in which it is embedded, and the political, economic, and social circumstances that determine its form. Less often, Kulturwissenschaftliche Literaturwissen-

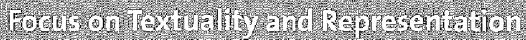

Cultural studies within English Studies is bound to analyse "culture as text," that is, textual manifestations of British cultures, whereby films and even "the internet" and architecture are also considered "texts" (Sommer, Grundkurs 5, 65, 85). It is such limited understanding of both texts as (cultural) representations, waiting to be hermeneutically/semiotically interpreted, and sociological research, which is apparently coming to its conclusions without interpreting culture, that makes a new conceptualisation of the discipline difficult. If anything, it is the inability to adopt "non-representational theories" ("Thrift) that might lead to a "loss of prestige of our discipline." "Representation," however, made it possible for Literary Studies to allow cultural studies perspectives into its field with out fundamentally changing its approach. The common defence against cultural studies by Literary Studies proponents can be summarised as follows: "critics of sociological approaches to popular culture point to methodology as the main problem: English Studies are [sic] not an empirical discipline and thus never concerned with cultural processes as such, but a textual science concerned with the analysis and interpretation of representations, of those processes" (Sommer, "From Cultural Studies" 179-80). 'Representations,' in this approach, seem to be easily separated from 'cultural processes as such'-as if representations were not part of cultural processes, as if 'representations,' could exist without being cultural artefacts, not only re-presenting 'cultural processes' after the fact, but forming and prefiguring them by laying out models, schemata, scripts, distinctions, values, etc.-as if representations, even more importantly, were not present in cultural processes. 
schaft examines the effects of literature, of its canonization and tradition, on culture and society. What it does not consider is the presence of literature in cultural processes. Cultural studies (as opposed to 'cultural studies literary studies'), under this paradigm, is to deal with everything that is not literature: TV, cinema, video games, pop music, etc.-within the methodological and theoretical framework of literary studies, however. In this way, apparently, English Studies could regain relevancy without getting its hands dirty at the 'grubby worldliness' of culture.

\section{4 | Cultural Studies, Kulturwissenschaft, and Medienwissenschaft}

In German-speaking countries, the study of culture had a tradition of its own long before the advent of British Cultural Studies in the 1980s. Philosophers and sociologists discussed and analysed the role of culture in society since at least the late eighteenth century (Kittler; Böhme et al.). While there is no space here to recapitulate this story, I want to highlight one specific moment in this history that shares some significant features with the British developments in the late 1950s. In the 1920 s, building on the groundbreaking work by sociologists of culture like Georg Simmel and Max Weber, a group of (secular) Jewish intellectuals brought together various ideas then circulating and, although not a 'school' in the narrow sense, created a research perspective that might be able to add to the study of culture what cultural studies might lack: history and materiality. Like their British working class counterparts, these researchers also argued from the margins of cultures and disciplines.

Emst cassiver, a professor of philosophy in Hamburg before the Nazis forced him to emigrate to New York, shifted attention away from the study of mind (Geistesuissenschaften) to that of cultural expressions. In his central three-volume work Die Philosophie der symbolischen Formen (1923-1929), Cassirer emphasises the active role of symbolic forms (art, language, myths, law, etc.) in the construction of the (meaningful) world humans inhabit. Cultural products were no longer thought of as either representations of universal ideas or subjective expressions of the human mind, but as an emergent level in the organisation of cultural patterns; culture, here, is not only something produced, but also something prođuctive.

Watter Benjamin, like his successors at the CCCS, was a bold trespasser of disciplinary boundaries, writing on literature, film, art, shopping arcades, and street lighting alike. Following Cassirer, Benjamin highlights the constructive role of media: "The way in which human perception is or- ganised-the medium in which it occurs-is conditioned not only by nature but by history" (23). In his studies of literature and film, Benjamin emphasises especially the role of technological media (the printing press, the cinematic apparatus) in the production and reception of cultural products: the same story told by an oral narrator or read in a novel is no longer the same story, the mechanically reproduced image no longer the same as the original painting. Media change what we see in cultural products, and, consequentily, how we see the world. It is not only the materiality of media and its influence on signifying processes that Benjamin highlighted, but the importance of the material world in general (street lamps, shopping malls) in the creation of cultural meaning. As a consequence, the study of culture becomes reciprocal the very concepts that we use to interpret the semantics of cultural products are formed by the media that bring these into existence. A safe vantage point from which to observe such contingent developments becomes as hard to find as a place outside history-or culture. Media, in the basic sense developed by Benjamin, are the very places where meaning and materiality are forever intricately in terwoven

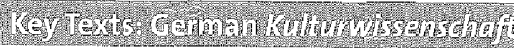

Ernst Cassirer; Die Philosophie der symbolischen Formen (3 vols., 1923-1929)

Walter Benjamin, "Das Kunstwerk im Zeitalter seiner technischen Reproduzierbarkeit" (1936)

Walter Benjamin, Das Passagenwerk. (1927-1940, unfinished)

Siegfried Kracauer, Die Angestellten (1930) Aby Warburg, Der Bilderatlas MNEMOSYNE (posthumous; 1929)

Theodor W. Adorno and Max Horkheimer, Dialektik der Aufklärung (1944/1947) 
Siagried Kracturer, too, began to analyse the everyday worlds of urban entertainment. Like Benjamin, with whom he collaborated at the Frankfurter Zeitung throughout the 1920 s, Kracauer was a keen observer of everyday culture, writing about film, design, advertising, tourism, cabaret, architecture, dime novels, and related topics; like Benjamin, and like Williams and Hall, too, Kracauer was looking for ways of renewing Marxist thought, adding cultural forces, values, and ideologies, to those of history and economy. It was of central importance to Kracauer, therefore, to find a method of analysis that made possible the combination of empirical observations and theoretical approaches that guide such observations. For him, the study of everyday culture is more political than any explicitly political critique dedicated to "extreme cases-war, crude miscarriages of justice, the May riots, etc." (Kracauer 101). Only in the study of everyday culture can the reflexivity of meaning and materiality, each forming the other, be observed. The tube-stations, shopping malls, and amusement parks Kracauer studies could be read as 'symptoms' of an age; more importantly, however, the media and materialities observed condition the very possibilities of interpreting them. The objects that Kracauer examines are not only (performative) signs, but media in the formative sense that Benjamin emphasised.

Such reciprocal determinations within an emergent and contingent culture can neither be studied solely by pure empirical observation nor without it. Kracauer's description of a methodology particular to the study of culture seems to me as fresh and important today as it must have been in 1930, and therefore worth quoting at length:

For a number of years now, reportage has enjoyed in Germany the highest favour among all types of representation, since it alone is said to be able to capture life unposed. Writers scarcely know any higher ambition than to report; the reproduction of observed reality is the order of the day. A hunger for directness that is undoubtedly a consequence of the malnutrition caused by German idealism [read today: French theory, C. H.]. Reportage [read today: philology, C.H.], as the self-declaration of concrete existence, is counterposed to the abstractness of idealist thought, incapable of approaching reality through any mediation. But existence is not captured by being at best duplicated in reportage. The latter has been a legitimate counterblow against idealism, nothing more. For it merely loses its way in the life that idealism cannot find, which is equally unapproachable for both of them. [...] Certainly life must be observed for it to appear. Yet it is by no means contained in the more or less random observational results of reportage; rather, it is to be found solely in the mosaic that is assembled from single observations on the basis of comprehension of their meaning. (32)
'Observations' and 'comprehension,' 'sociological research' and 'hermeneutic studies,' here, are no longer oppositions, but different aspects that have to be fruitfully combined if the contingency of $\mathrm{cul}^{-}$ ture, based on the possibilities of materiality and the potentialities of meaning alike, is to be studied.

Aby Waburg, in whose Kulturwissenschaftliche Bibliothek Ernst Cassirer was a regular visitor, worked as an art historian who integrated his analyses of paintings in a context of a wider visual culture that includes press photography, advertising, and stamps. His examinations were crossing cultural boundaries between high and low, and also between regional cultures. Equally important, however, was his diachronic view of culture, revealing the forgetting and remembering (cf. entry II.11), the repression and canonisation of figures and motives through the ages. This attention to the work of memory has become central to the study of culture in Germany. (After Warburg's death in 1929, his library was transported to London in order to save it from the Nazis.)

Theodor W. Adomo and Max Horkheiner, who collaborated with Walter Benjamin at the Institut für Sozialforschung, continued the analysis of popular culture after the war, albeit with a different impetus, in their famous Dialektik der Aufklärung (1944/1947). Horkheimer and Adorno, equally under the influence of the Nazi-propaganda that drove them to emigrate to the USA and the Hollywood schmaltz that welcomed them, identify the mass media and the 'culture industry' as purely conservative forces that promote the values of a capitalistic society and dupe consumers into passive acceptance of such a state. It is this negative opposition of mass culture to folk culture that became one of the stepping stones for (British) Cultural Studies.

"Cerman Media Theory", old and New. All in all, the Kulturwissenschaftler of the 1920 s and $1930 \mathrm{~s}$ had discovered many of the same topics that British Cultural Studies highlighted in the 1950s and 1960s: (popular) culture, mass media, visual forms, power, practice, marginalisation. More than their British counterparts, they focused on the materiality and the formative powers of media, but also on the historicity of cultural forms. Following this lead, German Studies developed its own branch of Medienkulturwissenschaft (e.g. Siegfried J. Schmidt, Friedrich Kittler, Hartmut Böhme), emphasising the role of mediality in all forms of culture; mediality, therefore, goes beyond the study of contemporary mass media (cf. entry

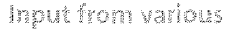
dimprimes 
III.5). But it is not only in Germany that the role of media is granted a more prominent place in the study of culture. Warner and Siskin, after their pleading for "Stopping Cultural Studies," suggest an engagement with (historical) media in a section of their essay entitled 'Starting.' Also, New Cultural
Studies, a collection of a self-proclaimed 'new generation' of (British) Cultural Studies proponents (Hall and Birchall), suggests, amongst other things, 'German Media Theory' as an important contributor to a new form of cultural studies.

\subsection{Theory and Methodology of Cultural (Media) Studies}

gemodeling Ertwish/English Studie. That "[c]ultural studies has not paid much attention to the classical questions of research methods and methodology" (Barker 31) is a claim so often repeated that some scholars have started to celebrate it as an achievement of freedom. Today, however, the study of culture can no longer claim a marginal position that would justify a consequent preference for exploratory, eclectic, and politically engaged studies. Thus, if the study of culture is to have a future within English Studies, its central concerns and methodologies should be clarified. The aim of this section, then, is to remodel British/ English Studies (Anglistik) as a form of cultural studies in which the study of language, literature, and media are three integrated and supplementary sub-disciplines of a discipline that revolves around historical manifestations of a specific cultural area and era. On the basis of those stories of origin narrated above, I will try to sketch the outlines of a possible path into the future of the study of British/English cultures.

The aim of the following section, then, is neither to provide a complete theory of culture nor to provide a comprehensive set of research techniques. Rather, I want to suggest a model of English Studies in general, and cultural (media) studies within English Studies especially, that identifies objects of research and provides a frame for possible approaches to these objects; such a theoretical model and methodology is derived from the practice of English Studies rather than a philosophical, sociological, psychological or other (grand) theory that was never devised to deal with culture, let alone cultural products. This is not to say that such theories are not valuable as background knowledge and inspiration for English Studies, or that they cannot enable valuable approaches-they are just not useful as a theoretical framework for English Studies, I think. Theory, here, is not a master-narrative (Marxism, psychoanalysis, deconstruction; cf. entries II.2.3, II.7, and
II.4) which the study of literature and other cultural products can only confirm, or not; rather, this theoretical model is to provide nothing more, and nothing less, than a framework for open-ended research questions. That such a theoretical model is not without its own premises, that it is not neutral, goes without saying; what these premises are shall be elaborated in the following.

My definition of English Studies (Anglistik) begins with an acknowledgement that it is part of cultural studies in the general sense of Kulturwissenschaften. Its aim is to provide observations of everyday (signifying) practices giving meaning to social life, in so far as these practices are condensed and manifested in linguistic and non-linguistic media. If culture is made up of the various social processes whereby humans make sense of their worlds, one way to access these meanings is their (iterative, symbolic) communications. Hence, culture goes beyond art and includes all social practices through which individuals interpret and define their worlds and find their place in it. English Studies' objects of analysis and interpretation are contingent and condensed manifestations of historically and culturally specific processes of creating, disseminating, transferring, and regulating meaning; particular attention is given to the material and media conditions of these communicative manifestations.

These objects of research are termed "cultural condensations" (Beck 48) here, rather than continuing the hypostatization that comes with the term 'cultural product.' Cultural condensations are not solely 'works' produced by individual artists, but visually, audibly, and haptically perceptible formations of and within culture; nonetheless, English Studies concentrates on lasting condensations rather than transitory formations, such as dances or similar rituals (Posner 51). 'Cultural condensations" are related to those precipitations that Williams distinguishes from culture in solution; in the terms of systems theory, condensations are tight 
couplings of those elements of culture that remain unobservable in their usual state of loose coupling (Luhmann, Gesellschaft 198-201). Only in the form of tight couplings, i.e. condensations, can culture be disseminated, transferred, and negotiated.

The focus of research in English Studies lies on revealing the constructedness of traditions and knowledge regimes (cf. section II.4.2) as well as of personal and collective identities, that is, to disclose the processual character of the condensation of meaning in its historical and cultural variability as well as their functions and effects. The tight couplings of cultural elements, articulations in Stuart Hall's sense, feed back on the culture from which they emerge. (When trying to understand such processes, however, it is obligatory to consider one's own historically and culturally specific observer position.)

The purpose of these (second-order) observations and reconstructions is to help society understand itself by teaching individuals how to interpret those cultural condensations that form their identities, and which create the very horizons that shape these interpretations. At best, such studies can enable students to gain sovereignty over their culture, to realise the contingency of its state and to envision alternatives. Central to English Studies, therefore, is the education of students who can transfer the results of such reflections back into society, as teachers or cultural workers in general. (Complex didactic, instructive, and communicational skills and proficiencies are, of course, prerequisites for such transfer.)

English Studies concentrates on processes of creating, disseminating, and regulating meaning in English-speaking cultural areas (for an example see entry IV.5), but also considers the effects of the acculturation of cultural condensations from Great Britain in other cultural areas, especially Germany. It draws on several disciplinary approaches (cf. the respective entries in this volume):

inguistice concentrates on the development, structure, and use of the English language, its historical and cultural variability as well as the regulating processes that determine these variations and the cultural identities these engender. As language is key to communication and consequently constitutive to the formation of culture, linguistics is key to the study of culture-a culture of which one is, qua language, always already a part.

literary studies focuses on textual communications and their relations to other media. Special attention is given to fictional texts that enable the exploration of alternative or hitherto unrealised interpretations of reality; such traditions, knowledge regimes, and identities are to be analysed in relation to their specific historical, political, institutional, and social contexts. In order to understand these relations to heteronomous forces, literary studies concentrates on the autonomous structures of texts, the specific forms, techniques, and traditions of texts that enable the recognition of alien perspectives and the revelation of new ones. As literature reflects everyday uses of language, and as few other cultural condensations know a similar history of autonomous structures, the study of literature has an important position within English Studies, both historically and methodologically.

cutural Media Studies, as the third component of English Studies, concentrates on multimedia cultural condensations, building on the semantic and textual work of Linguistics and Literary Studies, including visual, auditory, and material formations as well. Emphasizing the media-material condition and the pragmatic dimension of cultural condensations, cultural media studies is concerned with the technological, economic, institutional, political, ecological, and receptive determinants of cultural condensations as well as the reciprocal determinants of materiality, semantics, and pragmatics. Rather than concentrate on aesthetic objects only, as literary studies does, cultural media studies also

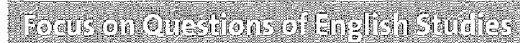

English Studies as Kutturwissenschaft analyses the functions of cultural condensations, that is, the creation, negotiation, dissemination, affirmation, regulation, and negation of cultural norms and values through cultural artefacts. Artefacts, thus, can be analysed as cultural condensations, if they can be related to the creation, negotiation, affirmation, and negation of cultural norms and values. While culture is its raison d'être, English studies, according to this model, takes cultural condensations as its methodological vantage point. Such cultural condensations are then questioned

- for their embeddedness within social practices,

- for their relations to (imaginary) horizons of norms and values, and

- for their material determinants.

These aspects of cultural condensations are examined in order to determine their function for the meaning-producing recipient-consumer:

- Why does an individual turn to a specific artefact?

- What can it tell him/her?

- How can it influence him/her?

To understand this, one also has to understand the socio-cultural environment and the material basis of cultural condensations - but only in so far as they are relevant for the study of the relation between cultural meaning, materiality, and (human) actors. 
Studying cuttura condensations examines the aisthetic dimension of our everyday environment (Böhme 17).

There are, of course, other forms of cultural studies possible (Johnson)-but this is the one I see most promising for evolving the traditions and qualifications of English Studies. Cultural practices less condensed, less mediated, less linguistic, and less permanent are the objects of ethnology, anthropology, sociology, and others.

Cultural condensations, under this definition, are analysed because they promise access to the social self-interpretation of specific groups at particular times. In this sense, they could be described as second-order mirrors (Stichweh 87). Here, individuals are not directly looking at themselves, i.e. they cannot read books or see films and simply identify what their culture is like; instead, they have to look at others looking at others and deduce (speculatively) the average value of other people's observations to form a 'compact impression' (Luhmann, Gesellschaft 597) of the world they live in. While sense-making is an individual process, it cannot be practised alone; through cultural sense-making the individual is connected to society; the meaning of signs is always already shared. Cultural condensations do not deliver representations of the world, but, at best, a shared interpretation of the world; this way, contingent condensation can provide orientation within contingent cultures. Why certain cultural condensations gain a representative status, and why others are marginalised, is a central research question rather than a starting point.

What is more, cultural condensations are more than mere representations of 'grubby worldliness,' they are part of this world. Contrary to a purely (poststructuralist) semiotic point of view, cultural media studies does not hold that "the object is nothing," that "it matters little what object is involved" (Baudrillard 63, 64) in the meaning creating processes of a culture. But neither do material objects determine their own meanings autonomously. Instead, such 'things'

participate in social practices just as human beings do. To be sure, these things are 'interpreted' by the human agents in certain ways, but at the same time they are applied, used, and must be handled within their own materiality. [...] 'Things' thus have the status of 'hybrids'; On the one hand, they are definitively not a physical world as such, within practices they are socially and culturally interpreted and handled. On the other hand, these quasi-objects are definitively more than the content of cultural 'representations,': they are used and have effects in their materiality. (Reckwitz 208-9)
Cultural condensations are hybrids of potentiality and actuality, meaning and materiality. Examples for cultural condensations relevant to English Studies are films, plays, books, but also games, packaging, and buildings, in short: everything that is at the same time part of our world and forms a distinctively structured realm of itself. Cultural condensations neither imitate a forgone world, nor figure the invisible structures of such a world, but participate in it; they are articulations, tight couplings of an unobservable culture. They can, of course, present themselves as mere (fictional) representations, and they can also be received as doing so-in doing so, however, they participate in constituting the very world they claim to re-present. Cultural condensations are products of a culture, but they also produce culture. Whereas culture, however, remains a speculative entity, cultural condensations exist (Konersmann 8). Concentrating on cultural condensations, it becomes necessary to relate meaning and materiality in non-reductive ways, and it is in this sense that Williams' cultural materialism proposes "the analysis of all forms of signification, including [...] writing, within the actual means and conditions of their production" (Writing in Society 210); the relation between meaning and materiality, here, is a matter of (historical) contingency, neither necessary nor arbitrary.

New research paradigms, finally, ask for new methodological approaches. Traditional hermeneutic and semiotic procedures form a sturdy basis for analysing the semantics of cultural condensations. However, if one is interested in materialities and practices also, new, empirical methods must be tried that can answer questions about production, circulation, reception, and consumption. The hybrid status of cultural condensations as meaning and materiality (in practice) demands a combination of methods of understanding and explaining. While meaning has to be understood, materiality is open to empirical research, even if only through the archive; the perspective of the actor, finally, can be examined by phenomenological and ethnographic methods as well as reception studies. If we agree that the media-materiality of the cultural condensation informs the very way in which actors interpret it, we will have to employ hermeneutic procedures on the basis of empirical reconstructions of materiality (Koschorke 11). Contingency means that every specific cultural formation is neither the way it is by necessity nor arbitrarily so. As a new paradigm 
for research, contingency demands that we analyse both how something became what it is (Genesis) and why it is valued over other possible states (Geltung); we have to explain what is and understand which options have remained latent. As there is no causality in the development of cultures, we have to interpret the interpretations that led to its existence; as the development of cul tural formations is no pure coincidence, we can trace their path empirically.

Cultural condensations, finally, can be examined according to three dimensions. This model (see box), aithough simplifying matters, should provide orientation to the following explications.

Meaning. First of all, there is the dimension of meaning, in the sense of a semiotic figuration that consists of any combination of textual, visual or auditory signs: a detective novel, a Shakespeare drama, a rock album, a video game, a Wordsworth poem, a thriller movie, a dress or a guildhall. Such semiotic figurations, of course, cannot be understood without reference to other diachronic and synchronic 'texts' and contexts. In order to understand a given semiotic figuration it is necessary to know its history, the genre rules it follows and the language regimes it partakes in, and the difference it makes compared to other 'texts' within a given discourse. As semiotic figurations, cultural condensations refer to (possible) worlds, although never directly: every signifier refers to a signified that mediates between sign and world.

Materialty. However, no image, no song, and no book merely refers to something other than itself (reference) - they also present themselves in their own existence, they reveal their own materiality, although in varying degrees, a dress maybe more so than a poem. Semiotic figurations stand in a double relation to the (material) world. On the one hand, they refer to it. On the other hand, every signified needs a material signifier to be perceivable through the senses. The material mediality that meaning employs to become, however, shapes this very meaning in an act of mediation-the words we use to communicate, for example, contribute to what we say as much as to what we think. Only as materiality can texts be stored and disseminated, can they be presented and passed on. Because semiotic figurations need materiality, they become part of economic and technological processes. However, a signifier can only be related to a signified because somebody does this relating; a sign is a sign only for someone: an individual, an actor. Consequently, cultural condensations exist

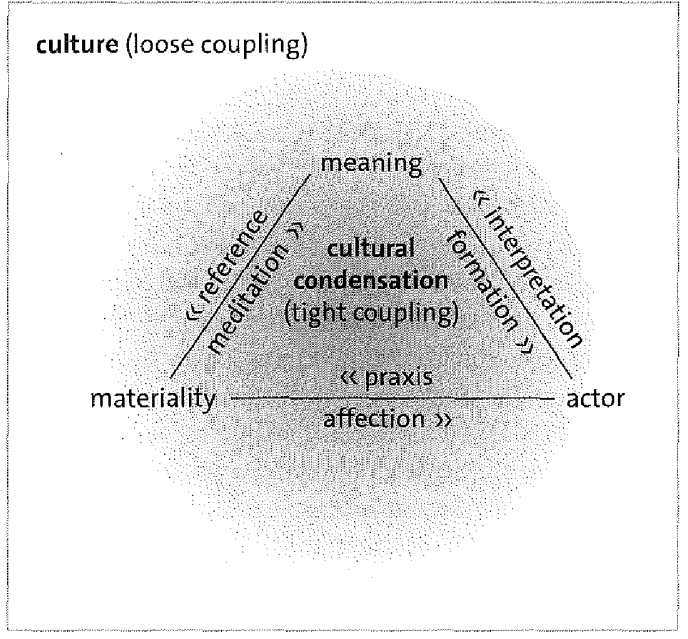

culvaral condeneations are we contolyeds of a retormed twing studies With mowang, materialy and actors as their mos? relewant ashers. within the triangular force field of meaning, materiality, and actor.

The actor, of course, does not exist independently of the semantic figuration s/he observes; s/he simultaneously observes (= follows) the rules of the semantic figuration s/he observes (= reads), s/he forms what $\mathrm{s} /$ he observes and is being formed by it. The actor's very subject position, the scripts, schemata, and distinctions s/he employs in order to interpret, are shaped and formed by the semantic figuration $\mathrm{s} /$ he consumes (formation); 'subjects' interpret cultural condensations and are in turn formed by the culture from which these condensations emerge and to which they contribute. Through the use of such cultural condensations, every actor becomes part of a larger formation, i.e. a particular culture. The actor's individual stance, finally, is a function of culture-which is always social.

What is more, the process of observing is not only a cognitive-intellectual procedure. The actor as a hermeneutic being is bound to a specific place and space, to a specific (material) history by the actor's corporeal existence that determines the individuality of his/her interpretations; the stance of the actor is thus both a prerequisite and a consequence of his/her encounter with cultural condensations. The corporeal stance of the actor also ensures that this encounter goes beyond volitional interpretation. As a material artefact, the cultural condensation exists in the same world as the actor, who is affected by both the materiality of the signifier and the material world the signified refers to; at the same time, the actor is subject to the visual and aural regimes that cultural condensations pro- 
The example of tourist guidebooks to the Lake District duce and partake in. Actors, finally, do not only exist corporeally and consequently re-act affectively to the materiality of the wor(l)d. They also act on and interact with this materiality, handling artefacts according to their specific materiality within specific spatial arrangements and a specific social praxis-they scratch with records and use the 'walkman' to find privacy in public places. It is such a triangulation of meaning, materiatity, and actor that can be employed in order to examine cultural condensations as articulations of culture.

Exemplarity and trmbeddedness. Such a complex triangulation of cultural condensations can only be performed exemplarily for historically and culturally specific occurrences. To understand the British culture, or even the English-speaking culture and the impact of its cultural condensations on other cultures is a task without end. Rather, the work of cultural condensations and their contribution to the contingency of cultures is to be revealed exemplarily-not at least in order to teach the method of second-order observation. Nonetheless, particular studies are meaningless as long às they are not embedded in a more global perspective that reveals repeating patterns as well as discontinuities over time and across cultures; identity and

\section{6 | Future Cultural (Media) Studies}

The establishment of cultural media studies in the way outlined above within a reformed discipline of English Studies would make it necessary to devise a new curriculum focussing on questions of culture. Linguistics, then, would ask about the role language plays within culture, and how the English language itself has been formed by Anglo-American cultures. Literary studies would ask about the role literature plays within Anglo-American cultures, and how literature itself has been formed by these cultures. Cultural media studies would ask how other cultural condensations (films, video games, music videos, etc.) contribute to Anglo-American cultures, and how they themselves are in turn formed by these cultures. Finally, a transcultural perspective would be necessary to understand the formation of differences and identities through comparison. The aim of research and teaching would be to reveal contingencies and enable reflective and refined self-observation. Pragmatic concerns like media literacy or direct political action cannot be central; rather, research difference, as I tried to explain, are matters of comparison. Even something as specific as, for exam ple, tourist guidebooks to the Lake District in the mid-nineteenth century are connected to largescale social transformations the emergence of a leisure class), material revolutions (the introduc tion of the railway system), new mentalities (romanticizing nature), and new social practices (colonial travel). A particular phenomenon cannot be understood without reference to wider developments which in turn can only be revealed through particular analyses. Detailed descriptions have to lead to abstract terminology and theories, as much as such terminology has to be employed to interrogate specific phenomena; at the same time, this terminology has to be refined in this process of interrogation. Central to such hermeneutic procedure, also, is the acknowledgement of the researcher's particular stance: his/her theoretical paradigm, institutional practices, and individual preferences bond the researcher to his/her context in the same way as the actor is bound to his/hers. English Studies in Germany, for example, practices cultural hermeneutics (cf. entry II.2) from a different starting point as do similar endeavours in the U.S. or Great Britain.

should produce a surplus of meaningful possibilities from which society (politics, protest movements, art, economy) is then to select. That cultural patterns are contingent forms means that they can be changed, but not just so-if they have become what they are through history, new cultural patterns have to create their own histories to gain stability.

English Studies after cultural studies-in the sense of: having gone through cultural studies (and poststructuralism) and coming out the better-would neither be a 'study of everything,' nor a return to philology, but the study of cultural condensations, both formed by their specific historical circumstances and producing these in turn. In order to be able to do so, English Studies has to employ historical, political, economic, and sociological studies in the way that we use, for example, computers; that is, it has to be able to handle the results of such studies critically, but it does not necessarily have to be able to produce these results itself. Instead of doing the work of historians, 
economists, sociologists, and others, English Studies has to be able to build on the results of these disciplines. When it comes to cultural condensations, however, English Studies should be able to examine empirically the history, economy, and praxis of such manifestations. Rewarding new research, therefore, will not be possible without a broad knowledge of the findings of relevant related disciplines, a thorough familiarity with the history of one's own discipline, methodological rigour, and theoretical validation.

To establish this will probably take a few (academic) generations-if it ever happens. The task at hand differs greatly from what has been done so far: it is neither another turn asking to look at the same old phenomena (texts) from yet another angle; neither is it about looking at new phenomena (comics, music videos, etc.) from a well-known angle (psychoanalysis, semiotics, etc.). A truly reformed English Studies asks for a completely new form of knowledge that allows those that have acquired it to analyse cultural condensations both as productions and producers of (social) realities. One has to become, as the CCCS required from the beginning, both an expert in culture and society, literary studies and sociology-and, if possible, also in film and art studies, history, ethnology, anthropology, etc. To achieve this daunting task, we not only need a theoretical foundation for the study of culture (which we are getting close to) and a fitting set of methodologies (which are still

\section{Select Bibliography}

Arnold, Matthew. Literature and Dogma: An Essay Towards a Better Apprehension of the Bible. London: Smith, Elder \& Co., 1891.

Baecker, Dirk. "Globalisierung und kulturelle Kompetenz." Wozu Kultur? Ed. Dirk Baecker. Berlin: Kulturverlag Kad mos, 2003. 11-32.

Barker, Chris. Cultural Studies: Theory and Practice, $3^{\text {rd }}$ ed. Los Angeles: Sage, 2008.

Bateson, Gregory. "Culture Contact and Schismogenesis." 1935. Steps to an Ecology of Mind. New York: Ballantine 1972. $61-72$

Baudrillard, Jean. For a Critique of the Political Economy of the Sign. St. Louis: Telos, 1981.

Beck, Ulrich. Ecological Politics in an Age of Risk. 1988. Trans. Amos Weisz. Cambridge: Polity Press, 1995

Benjamin, Walter. The Work of Art in the Age of its Technological Reproducibility, and other Writings on Media. 1936. Ed. Michael William Jennings. Harvard: Harvard University Press, 2008.

Böhme, Gernot. Aisthetik: Vorlesungen über Ästhetik als allgemeine Wahrnehmungslehre. Munich: Fink, 2001 slow in coming), but also an adequate curriculum and disciplinary setting (which is nowhere yet to be seen).

If you think this is an impossible task, think again, and consider the various fields a medical scientist has to be an expert in: chemistry, biology, physics, psychology, surgical crafts, etc. The medical profession, consequently, asks for a curriculum that seems to be amongst the most demanding: to study humans is considered to be one of the most complex tasks in the world, and students are eager to invest heavily to learn the trade. But if humans are such complex systems, how complex is that which all humans who ever lived have created together, that is, culture? Why should it be less demanding to study cultures than to study humans? And why should it be less rewarding (at least intellectually)?

Just as medicine does not make physics, chemistry, and so on obsolete, the study of (British) cultural condensations does not make obsolete media studies, literary studies, art history, sociology, ethnology, anthropology, economics, etc. Rather, like medicine, using other knowledge systems selectively for the study of humans, the study of cultural condensations uses the aforementioned knowledge systems to understand such cultural condensations and the cultures that create themor at least to open a space between being made and making, between actuality and potentiality.

Böhme, Hartmut, et al. Orientierung Kulturwissenschaft: Was sie kann, was sie will. 3 rd ed. Reinbek: Rowohlt, 2007.

Bromley, Roger. "Cultural Studies gestern und heute." Cultural Studies: Grundiagentexte zur Einfuhrung. Eds. Roger Bromley, Udo Göttlich, and Carsten Winter. Lüneburg: zu Klampen, 1999. 9-24.

Cassirer, Ernst. Die Philosophie der symbolischen Formen. $1923-1929,3$ vols. Hamburg: Meiner, 2010.

Eagleton, Terry. The Idea of Culture. Oxford: Blackwell, 2000.

Frühwald, Wolfgang, et al. Geisteswissenschaften heute: Eine Denkschrift. Frankfurt/M.: Suhrkamp, 1991.

Gilroy, Paul. There Ain't no Black in the Union Jack: The Cultural Politics of Race and Nation. London: Hutchinson, 1987.

Hall, Gary, and Clare Birchall, eds. New Cultural Studies: Adventures in Theory. Edinburgh: Edinburgh University Press, 2006

Hall, Stuart. "The Emergence of Cultural Studies and the Crisis of the Humanities." The Humanities as Social Technology 53 (1990): 11-23.

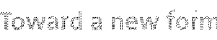

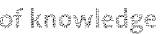


Hall, Stuart. Interview by Colin MacCabe. Critical Quarterly 50 (2008): $12-42$.

Hall, Stuart. "On Postmodernism and Articulation: An Interview with Stuart Hall, by Lawrence Grossberg." Jour nal of Communication Inquiry 10,2 (1986): 45-60.

Hebdige, Dick. Subculture: The Meaning of Style. London: Methuen, 1979.

Hoggart, Richard. The Uses of Literacy: Aspects of Working-Class Life with Special Reference to Publications and Entertainments. 1957. New Brunswick: Transaction Publishers, 1992

Huck, Christian, and Carsten Schinko. "The Medial Limits of Culture: Culture as Text vs. Text as Culture." GrenzGänge-BorderCrossings: Kulturtheoretische Perspektiven. Eds. Gerd Sebald, Michael Popp, and Jan Weyand. Münster: LIT, 2006. 57-71.

Johnson, Richard. "What is Cultural Studies Anyway?" What is Cultural Studies? A Reader. Ed. John Storey. London: Arnold, 1998. 75-114.

Kittler, Friedrich. Eine Kulturgeschichte der Kulturwissenschaft. Munich: Fink, 2000.

Konersmann, Ralf. Kulturphilosophie zur Einführung. Hamburg: Junius, 2003

Koschorke, Albrecht. Köperströme und Schriftverkehr: Mediologie des 18. Jahrhunderts. Munich: Fink, 1999.

Kracauer, Siegfried. The Salaried Masses: Duty and Distraction in Weimar Germany. 1930. Trans. Quintin Hoare. London: Verso, 1998.

Kramer, Jürgen, and Bernd Lenz. "Editorial." Journal for the Study of British Cultures 1.1 (1994): 3-7.

Lindner, Rolf. "Richard Hoggart ("1918): 'A shabby cat from the council house': The Uses of Literacy und das Centre for Contemporary Cultural Studies, Birmingham." Culture Club Il: Klassiker der Kulturtheorie. Eds. Martin Ludwig Hofmann, Tobias F. Kortas, and Sibylle Niekisch. Frankfurt/M.: Suhrkamp, 2006. 164-83.

Lindner, Rolf. Die Stunde der Cultural Studies. Vienna: WUV, 2000.

Luhmann, Niklas. Die Gesellschaft der Gesellschaft. Frankfurt/M.: Suhrkamp, 7998.

Luhmann, Niklas. Observations on Modernity. 1992. Trans. William Whobrey. Stanford: Stanford University Press, 1998.

McRobbie, Angela. Feminism and Youth Culture. London Routledge, 1990.

Nünning, Ansgar, and Jürgen Schlaeger. "Quo vadis, Anglistik? Recent Trends in and Challenges for English Studies." English Studies Today: Recent Developments and New Directions. Eds. Ansgar Nünning and Jürgen Schlaeger. Trier: WVT, 2007. 7-22.

Nünning, Ansgar, and Roy Sommer. "Kulturwissenschaftliche Literaturwissenschaft: Disziplinäre Ansätze, theoretische Positionen und transdisziplinäre Perspektiven." Kulturwissenschaftliche Literaturwissenschaft: disziplinäre Ansätze - theoretische Positionen - transdisziplinäre Perspektiven. Eds. Ansgar Nünning and Roy Sommer. Tübingen: Narr, 2004. 9-31.

Posner, Roland. "Kultursemiotik." Einführung in die Kulturwissenschaft: Theoretische Grundlagen-Ansätze-Perspektiven. Eds. Ansgar Nünning and Vera Nünning. Stuttgart: Metzler, 2008. 39-72.

Reckwitz, Andreas. "The Status of the 'Material' in Theories of Culture: From 'Social Structure' to 'Artefacts."
Journal for the Theory of Social Behaviour 32.2 (2002): $195-217$.

Sommer, Roy. "From Cultural Studies to the Study of Culture: Key Concepts and Methods." English Studies Today: Recent Developments and New Directions. Eds. Ansgar Nünning and Jürgen Schlaeger. Trier: WVT, 2007. 165-91.

Sommer, Roy. Grundkurs Cultural Studies / Kulturwissenschaft Großbritannien. Stuttgart: Klett, 2003.

Stichweh, Rudolf. Inklusion und Exklusion: Studien zur Gesellschaftstheorie. Bielefeld: transcript, 2005.

Stierstorfer, Klaus. "Einleitung: Anmerkungen zur Interdisziplinarität der Kulturwissenschaft." Kulturwissenschaft interdisziplinär. Eds. Klaus Stierstorfer and Laurenz Volkmann. Tübingen: Narr, 2005. 9-18.

Thrift, Nigel. Non-Representational Theory: Space-Politics-Affect. London: Routledge, 2007.

Tylor, Edward Burnett. Primitive Culture: Researches into the Development of Mythology, Philosophy, Religion, Language, Art and Custom. Vol 1. 1871. Whitefish: Kessinger, 2007.

Warner, William B., and Clifford Siskin. "Stopping Cultural Studies." Profession (2008): 94-107.

Weimann, Robert. "Towards a History of Twentieth-Century Anglistik: Cultural Studies and the Question of Aims and Methods." Anglistik: Research Paradigms and Institutional Policies:1930-200o. Ed. Stephan Kohl. Trier: WVT, 2005. 253-70.

Wiesing, Lambert. "Was sind Medien?" Was ist ein Medium? Eds. Stefan Münker and Alexander Roesler. Frankfurt/M.: Suhrkamp, 2008. 235-48.

Williams, Raymond. Culture and Society: 1780-1950. London: Chatto \& Windus, 1958.

Williams, Raymond. "Culture is Ordinary." 1958. Resources of Hope: Culture, Democracy, Socialism. Ed. Robin Gable. London: Verso, 1989. 3-18.

Williams, Raymond. "The Future of Cultural Studies." The Politics of Modernism: Against the New Conformists. Ed. Tony Pinkney. London: Verso, 1989. 151-62.

Williams, Raymond. The Long Revolution. London: Chatto \& Windus, 1961

Williams, Raymond. Marxism and Literature. Oxford: Oxford University Press, 1977.

Williams, Raymond. Writing in Society. London: Verso, 1983.

Willis, Paul. Learning to Labour: How Working-Class Kids Get Working-Class Jobs. Aldershot: Gower, 1977.

Winter, Rainer. Kunst des Eigensinns: Cultural Studies als Kritik der Macht. Weilerswist: Velbrück, 2001.

Christian Huck

(Much of section 2 was written with the help of Geneviève Nario-Rivera. An earlier version of the definition of Anglistik in section 5, although not the theoretical model, has been devised together with colleagues from both literary studies and linguistics in English and American studies, namely: Lieselotte Anderwald, Ute Berns, Roger Lüdeke, Birgit Neumann, and Erik Redling; they cannot be made responsible, however, for any misgivings in the current revised version. Moreover, I would like to thank Alexander Joachimsmeier, Stefan Bauernschmidt, and Doris Feldmann for valuable comments on earlier drafts of this text.) 